\title{
DOING JUSTICE TO THE TROUBLES: IMAGINARY RECONCILIATIONS AND RESTORATIVE MEMORY IN POST-AGREEMENT NORTHERN IRELAND
}

\begin{abstract}
This article addresses avenues for reconciliation and the persistence of the Troubles in Northern Ireland in the interconnected contexts of politics, remembrance culture and public discourse during the peace process, with particular attention focused on the operations of transitional justice and restorative memory (a category I derive from restorative justice and restorative truth). I argue that the peace process realities in Northern Ireland actively invite a mode of social and political evasion of the past by consigning recent history to cultural discourses, to be explored and chronicled mostly by works of fiction, rather than weighed on the scales of justice in the first place. Post-Troubles fiction offers carefully selected patterns, scripts and templates of the past (preserved in 'restorative memory') which, rather unsurprisingly, tend to promote a mood of reconciliation over the idea of reckoning and retribution. Thereby fiction as such (exemplified here by David Park's The Truth Commissioner, Five Minutes of Heaven directed by Oliver Hirschbiegel and Lucy Caldwell's All the Beggars Riding) becomes a key player in the contemporary politics of memory.
\end{abstract}

Keywords: politics of memory, reconciliation, restorative memory, fiction, the Troubles, Good Friday Agreement, transitional justice, Truth Commission, truth recovery

The twentieth anniversary of the Good Friday Agreement is a good opportunity to assess how the Troubles have been preserved, represented and, not infrequently, misrepresented in the collective memory of the two major communities (the Unionists and the Nationalists) involved in the conflict in Northern Ireland. More specifically, I want to take a closer look at the interconnected contexts of politics, remembrance culture and public discourse during the peace process, with particular attention focused on the operations of transitional justice and restorative memory (a category I derive from restorative justice and restorative truth). With that in mind, I discuss several fictions that imaginatively explore legal and psychological avenues apparently too daring for real-life politicians and other individuals; for contrast and comparison, I set those fictions side by side with actual historical developments which are interpreted in light of prior declarations and avowed intentions of the key players in the province. It is my claim that the peace process realities in Northern Ireland 
actively invite a mode of social and political evasion of the past by consigning recent history to cultural discourses, to be explored mostly by (literary and filmic) fiction, rather than weighed on the scales of justice in the first place. Post-Troubles fiction offers carefully selected patterns, scripts and templates of the past (preserved in what I call restorative memory) which, rather unsurprisingly, tend to promote a mood of reconciliation over the idea of reckoning and retribution. Thereby fiction itself becomes a key player in the contemporary politics of memory.

In 2008 David Park published a controversial and much acclaimed novel titled The Truth Commissioner. The timing was crucial. Ten years after the Good Friday Agreement, during an impasse in the debates over the establishment of a transitional justice mechanism in Northern Ireland, Park offered an apparently painless experiment, a hypothetical experience of justice and truth recovery. The Truth Commissioner is set in a post-conflict Northern Ireland; the setting is quite realist, with a political configuration almost identical to the consociational arrangement arrived at after 1998. The key difference lies in an unexpected compromise reached over the introduction of the Truth Commission whose prerogatives are defined by one of the protagonists, Henry Stanfield, in the following words:

Firstly, we meet to give a voice to the victims of the violence, to remember those who have died or suffered and to try to help those who grieve to take the difficult and painful steps towards healing. Without this individual healing there can be no societal healing and without confronting our past in a spirit of reconciliation and understanding society can never build a better future. Secondly, we meet to try to initiate a process of healing through the establishment of truth and openness. Truth is vital if this society is to open itself to the possibility of communal atonement and bring closure to those whose suffering has been compounded by uncertainty and unanswered questions. ${ }^{1}$

Accordingly, Park's novel as such unfolds in two directions: first, the operations of the Commission illustrate the general mechanisms of transitional justice and its potential for truth recovery, and secondly, the plot digs into the past and the psychology of individual protagonists to uncover what a public investigation must remain blind to. As Shameem Black puts it, "The Truth Commissioner decenters the truth commission into a private space while relying on a convergence plot to provide the unities associated with commission procedures". ${ }^{2}$ Eventually, however, the minutiae of the characters' past lives are exposed to the reader to prove that no commission can ever comprehend the complexities of human biographies and the myriad choices they made under vastly complicated circumstances, which often elude representation after many years. What remains particularly unsettling, though, is that in contemporary Northern Ireland public truth recovery, sanctioned by a truth commission, is imaginable exclusively in fiction.

1 D. Park, The Truth Commissioner, London, New Delhi, New York \& Sydney: Bloomsbury, 2009, p. 317.

2 S. Black, "Truth Commission Thrillers", Social Text 2011, vol. 29, no. 2, p. 48. 


\section{Post-conflict realities}

To make sense of the political significance of Park's novel it is necessary to go back to the Troubles, just as The Truth Commissioner does. The conflict in Northern Ireland formally ended in 1998, with the Belfast Agreement, also known as the Good Friday Agreement (or, more formally: The Northern Ireland Peace Agreement), which proclaimed, among other things, both major communities' right to govern the province, i.e., to form a joint government based on the representatives of unionist and nationalist parties. The famous, or notorious, catch phrase 'parity of esteem' has become synonymous with the public discourse of reconciliation; the dominant rhetoric of healing being imposed even on those whose wounds were still fresh and festering (to the point that some even tried to impose this rhetoric on the dead). The Good Friday Agreement itself said very little about transitional justice and about truth recovery although it did mention reconciliation and the victims of the conflict (it "is essential to acknowledge and address the suffering of the victims of violence as a necessary element of reconciliation" ${ }^{\prime \prime}$ ); it was mostly concerned with the truce and reaching a political compromise in order to envision a better future (or "a fresh start"'). Without indicating any specific judicial bodies or seeking to launch any sort of truth commission at that stage, it made provisions for the establishment of appropriate institutions later on.

It may seem that the republican side was much more eager to have a transitional justice mechanism in place right after the conclusion of the Troubles. In 2003 Sinn Féin issued a declaration (a discussion document) called simply "Truth" in which they state their willingness to get involved in a truth commission in Northern Ireland on the condition that it is an international and independent body with a wide mandate, and no hierarchy of victims is assumed. Sinn Féin express their reservations about the effectiveness of the very process of truth recovery, describing the past experiences as equivocal. ${ }^{5}$ Still, they are determined to participate in investigating the root causes of the conflict and in identifying ways of preventing it from happening again as long as the process is victim-centred. There are several other general conditions and principles that they lay down in their proposal. Alongside the focus on the victims of the Troubles, the republicans insist that any jointly accepted ("full cooperation and disclosure") mechanism of truth recovery in Northern Ireland be politically neutral.

The Northern Ireland Peace Agreement (1998), available at: https://peacemaker.un.org/sites/peacemaker.un.org/files/IE\%20GB_980410_Northern\%20Ireland\%20Agreement.pdf, p. 20 [access: 13.06.2018].

$4 \quad$ Ibidem, p. 2.

5 Truth - A Sinn Féin Discussion Document, available at: http://www.sinnfein.ie/contents/993, p. 2 [access: 13.06.2018].

$6 \quad$ Ibidem, p. 4. 
Crucially, Sinn Féin suggest that a truth commission, while essentially concerned with truth recovery, is the best way to stimulate healing and building the peace. ${ }^{7}$

The 2003 Sinn Féin discussion document articulates far-reaching republican expectations connected with subjecting to public scrutiny not only paramilitary organizations on both sides of the conflict but also the media, the judiciary and various state institutions in Northern Ireland. One of its ulterior motives was, no doubt, to expose cases of state collusion, including mostly collusion between RUC and the loyalists ${ }^{8}$ but also state support of terrorism. ${ }^{9}$ It is not surprising, then, that "Truth" was not received enthusiastically by all parties concerned. Even if it sincerely meant to heal the patient, applied consistently, in all likelihood it would have aggravated the symptoms of Northern Irish schizophrenia. In the 2000s both the unionist parties in Northern Ireland and the British Governement continued to express their concern about the volatility of the situation in the province while Sinn Féin refused to make any major concessions and accept a compromise. ${ }^{10}$ As a result, a genuine international truth commission has proved to be a non possum so far.

Commissions formed within Northern Ireland, and made up of representatives of local communities, have not proved to be successful, either. This is exemplified by the Consultative Group on the Past: it was established in June 2007 and had a limited mandate yet managed to produce a balanced and stimulating report in 2009, which included many sensible and stimulating recommendations. Regrettably, most of those were ignored. One of the recommendations involved the establishment of the Legacy Commission, a body following the model of truth commissions, with a similar mandate and remit. Still, it never came into existence: Sinn Féin's problem with both the Consultative Group on the Past and the Legacy Commission, apparently, was that neither was international and independent enough. In other words, to ensure that the process would also involve, e.g., investigating state collusion, Sinn Féin wanted to get the United Kingdom and its representatives at any level out of the equation during the formation or authorization of the truth commission. This could prove difficult, as in most cases transitional justice requires that the host state authorizes the operation of its mechanisms. ${ }^{11}$ Likewise, with most justice mechanisms and local institutions which have been established so far, it is the mistrust of the state and its apparatuses that drives the republicans away from them, at least that is what they claim. ${ }^{12}$

Ibidem, pp. 4-5.

8 See M. McGovern, “'See No Evil': Collusion in Northern Ireland”, Race \& Class 2017, vol. 58, no. 3 , p. 47.

9 See A. Fitz-Gibbon, Talking to Terrorists, Non-Violence, and Counter-Terrorism: Lessons from Gaza and Northern Ireland, London: Palgrave Macmillan, 2016, p. 27.

10 See P. Lundy, M. McGovern, "Attitudes towards a Truth Commission for Northern Ireland in relation to party political affiliation", Irish Political Studies 2007, vol. 22, no. 3, pp. 323-324.

11 See P.B. Hayner, Unspeakable Truths: Transitional Justice and the Challenge of Truth Commissions, New York \& London: Routledge, 2011, p. 12.

12 H. McDonald, "Northern Ireland violence triggered by ideology and a mistrust of the police", The Guardian, available at: https://www.theguardian.com/uk/2011/jul/12/northern-ireland-violence-ideology-police [access: 13.06.2018]. 
The formation of the Consultative Group on the Past was announced by Peter Hain, the Secretary of State for Northern Ireland. Even though he declared that it would be an independent commission whose task was "to seek a consensus across the community in Northern Ireland on the best way to deal with the legacy of the past", ${ }^{13}$ Sinn Féin were reluctant to acknowledge the political neutrality and authority of that body. ${ }^{14}$ The two co-chairs of The Consultative Group on the Past-Robin Eames (a former Church of Ireland Archbishop of Armagh and Primate of All Ireland) and Denis Bradley (a former vice-chairman of Northern Ireland Policing Board, also a former priest) - were supposed to even out political, ethnic and religious differences within the commission but instead their presence, it seems, constituted a pretext for Sinn Féin, and to some extent for the Irish government, to distance themselves from CGP as such. The group invited international experts to contribute in the advisory capacity, however, that did not cushion the criticism which the CGP's Report met with from all quarters, including the Democratic Unionist Party. Significantly, the isssue of the recognition payment aside, it was the identity of the group members that both sides of the conflict objected to. ${ }^{15}$

Determining a common past is one of the crucial issues addressed by the authors of the Report of the Consultative Group on the Past. Although the Report's social effect has been seriously mitigated by the controversy over the proposed recognition payment to the victims and their families ${ }^{16}$ some of the passages deserve close scrutiny for the more general implications that they carry. In a section which identifies the purpose of remembrance of the past as reconciliation, the report suggests that storytelling ("remembering through the telling of stories" ${ }^{17}$ ) may perform a crucial role in truth recovery:

Divided communities carry different experiences and understandings of the past in their minds and indeed it is this that divides them. Their accounts of the past differ deeply. They are used as a marker to determine and make positive, but more frequently negative, moral judgments on each other and so continuing the legacy of suspicion, mistrust and hatred. These different moral assessments are seen most clearly in each side's often strident retelling of their own story. If these conflicting moral assessments of the past are to change, then all sides need to be encouraged and facilitated to listen and hear each other's stories. This listening must then lead to honest assessment of what the other is saying and to recognition of truth within their story. In such

13 Quoted in: D. Walsh, Independent Commissions and Contentious Issues in Post-Good Friday Agreement Northern Ireland, Cham: Palgrave Macmillan, 2017, pp. 137-138.

14 Ibidem, p. 130.

15 Ibidem, p. 133.

16 See T.G. Fraser, "Historical legacies and the Northern Ireland peace process: Issues of commemoration and memorialisation", Shared Space 2012, vol. 12, p. 276; D. Walsh, Independent Commissions..., p. 276.

17 Report of the Consultative Group on the Past, available at: http://cain.ulst.ac.uk/victims/docs/consultative_group/cgp_230109_report.pdf, p. 19 [access: 13.06.2018]. 
a process it might be possible to construct a remembrance of our past which is more humane, comprehensive and rounded. ${ }^{18}$

The epistemological encouragement to speak and listen to each other's stories implies a larger ethical encouragement to embrace the other's past as one's own. That is an act of memory; it is also an act of benevolence and sympathy. There will be no reconciliation without it: divided pasts will haunt consecutive generations of Catholics and Protestants in Northern Ireland until they take stock of their shared history, hand in hand, no judgments made. In other words, this is an encouragement for both major communities in Northern Ireland to take over the prerogatives of a truth commission and perform reconciliation in a less formal setting. Still, as Hackett and Rolston point out, ${ }^{19}$ there is a significant political dimension to storytelling, which may mitigate each individual's sense of commitment and responsibility for the process. In informal settings, too, storytelling involves interaction with audiences and exposure to criticism.

\section{Five Minutes of Heaven}

An opportunity for an honest exchange of stories is created in Five Minutes of Heaven, a 2009 film directed by Oliver Hirschbiegel. Alongside Park's The Truth Commissioner which I discuss further on, this is another case of imaginary reconciliation in Northern Ireland, significantly, offered by a German director and scripted by a British writer, Guy Hibbert. The emotional power of the drama rests almost entirely on the bravura performances by two Ballymena-born actors: Liam Neeson and James Nesbitt. The casting is of paramount importance here: Neeson, a Catholic, is invited to play a rehabilitated Protestant killer, apparently penitent and prepared to look in the eye of his victim's brother, while Nesbitt, who was born into a Presbyterian family, is cast as an unforgiving Catholic whose life was ruined by the Troubles. The actors were able to talk to the actual people whose story the film is based on: Neeson politely refused to meet his counterpart (Alistair Little) until they were done shooting his scenes whereas Nesbitt, once he saw the script, needed to verify the authenticity of his character and spent long hours talking to Joe Griffin. ${ }^{20}$

The actual killer, Alistair Little, and Joe Griffin never agreed to meet each other in real life. Hirschbiegel's film is the kind of prosthetic experience that only art can offer, the idea of acting out alternative identities reminiscent of Bert Hellinger's

18 Ibidem, p. 24.

19 C. Hackett, B. Rolston, "The burden of memory: Victims, storytelling and resistance in Northern Ireland", Memory Studies 2009, vol. 3, no. 2, p. 357.

20 See T. Rafferty, "After the troubles, telling different stories", The New York Times, available at: https:// www.nytimes.com/2009/08/16/movies/16raff.html [access: 13.06.2018]. 
method of family constellations in psychology. ${ }^{21}$ Within the film, the meeting is arranged for the benefit of a live audience in front of their TV sets, which both major characters are painfully aware of. Their reconciliation is not really meant to be theirs but entire society's; they are manipulated into a staged performance and that is why Joe is prepared to take matters (and justice) into his own hands (literally: he wants to kill Alistair with a knife). And yet it is this manipulation and their common plight in the new circumstances which are so much different from the black and white (one tends to think of the photos of the 1970s Belfast during the conflict) reality of the Troubles that make Joe's resolve fade away. On the way to the meeting, in the car, Joe summons the memories of his family home, the pain of his brother's death, including the blame his mother undeservedly put on him for the tragedy. The flashbacks are there to show us that the past keeps haunting Nesbitt's character, and yet, as the actor emphasises in an interview, in 2009, Joe Griffin himself proved to be an extremely lively, articulate and funny person..$^{22}$ Rather naively conceived, the actual encounter between the characters, which takes place in a deserted house, is supposed to cleanse them and relieve their traumas by releasing some physical tension. Inflicting wounds (literal traumas) on each other is to a large extent a way of diverting attention from the past rather than dealing with it, still this seems to be the best that Alistair can offer Joe by way of expiation, and Joe is benevolent enough to acknowledge that (the final phone call).

Overall, despite the classy performances by its two stars, Five Minutes of Heaven is a little too stagy to be effective as a powerful, resonant film, capable of captivating mass audiences. Its cinematography (handheld shots and the documentary footage at the beginning reminiscent of Bloody Sunday), the use of voice-over to convey Nesbitt's character's internal dialogue and the theme of prepping the guests of the TV show by the crew make the viewer acutely aware of a metadramatic dimension to it. It seems that asking two men with a past, contaminated by the Troubles, to forgive and forget is a futile gesture: poignant (and paradoxical) as it sounds, embarking on the process of reconciliation would be easier with a clean slate. Five Minutes of Heaven explores the issue (the im/possibility?) of a fresh start and, simultaneously, it illustrates a major problem which has bedevilled Northern Irish cinema for the last couple of decades: "Films set in the Northern Ireland conflict ... are uncomfortably close to the real world ... and the closeness of reality to films ... marks them as a potential threat to Ulster's precarious social order". ${ }^{23}$ Any attempt at mobilizing the collective memory of the Troubles is fraught with risks, and the consequences may be difficult to predict. The film's plotline alone shows how little control directors have over those

${ }^{21}$ See D.B. Cohen, ““Family constellations”: An innovative systemic phenomenological group process from Germany", The Family Journal: Counseling and Therapy for Couples and Families 2006, vol. 14 , no. 3, pp. 226-232.

22 T. Rafferty, "After the troubles...", emphasis mine (LD).

23 K.J. Donnelly, "The Policing of Cinema: Troubled film exhibition in Northern Ireland", Historical Journal of Film, Radio and Television 2000, vol. 20, no. 3, p. 385. 
whose past is to be recovered and exposed to the public. For many people the thin line between reality and fiction will not get thicker just because the film does not aspire to be family entertainment.

After the signing of the Good Friday Agreement many literary works and films have revisited the Troubles, exploring either Catholic or Protestant traumas. Five Minutes of Heaven, however, is unique in focusing on the post-Troubles perspective and offering an in-depth study of the protracted impact of sectarian violence: Hirschbiegel is particularly interested in what the past has done to the present and how his characters can adapt to contemporary circumstances. What is crucial about the politics of memory in the film is that the victims of the Troubles are not to be properly commemorated on the TV show; instead, Joe's brother (and his memory) is to be used for a prescribed (pre-scripted) vision of healing and reconciliation even if Joe's wound is still sore. Therefore inasmuch as Five Minutes of Heaven forays into an imaginary territory (the televised meeting between the killer and his victim's brother) where actual Joe Griffin and Alistair Little were not willing to tread, it also speaks to authentic social and political concerns that many people in Northern Ireland are quite familiar with. In other words, Hirschbiegel's film is not just a local colour story "inspired by two extraordinary lives" (as the back cover of my DVD reads); it lays bare some crucial "machinations of cultural memory" 24 in the Northern Irish context.

In that respect, Hirschbiegel's film has much in common with The Truth Commissioner by David Park, which I explore in some detail further on in this article. What makes those two works particularly interesting is that they combine the psychological and the political in ways which are revealing of cultural memory's dependence on fiction and fiction's responsibility for reconciliation and the peace process. This is not to say that other fiction writers and film-makers in Northern Ireland have not been interested in their local/regional history over the last twenty years. On the contrary, and to focus exclusively on novels first: such writers as Anna Burns (No Bones, 2001 and the most recent, Man Booker winning Milkman, 2018) Eoin McNamee (The Ultras, 2004), Lucy Caldwell (Where They Were Missed, 2006), David Park (Swallowing the Sun, 2004), and Glenn Patterson (Gull, 2016) have quite successfully reawakened the Ghosts of the Troubles Past in their works. Because of the time of their publication their novels have been collectively classified as post-Troubles or post-agreement literature $^{25}$ although most of them are set during the Troubles and in that sense they are historical fictions which illustrate and illuminate the workings of collective memory. Then there is a large number of quite popular films which address particular historical

24 O. Frawley, "Introduction: Cruxes in Irish Cultural Memory: The Famine and the Troubles", [in:] O. Frawley (ed.), Memory Ireland, vol. 3: The Famine and the Troubles, Syracuse, NY: Syracuse University Press, 2014, p. 14.

25 See M. McGuire, "Novel truths and post-troubles fiction: Eoin McNamee's The Ultras", Australian Journal of Irish Studies 2015, vol. 15, p. 55; B. Heidemann, Post-Agreement Northern Irish Literature: Lost in a Liminal Space?, London: Palgrave Macmillan, 2016, p. 5. 
events and themes from the final decades of the twentieth century. Bloody Sunday (2002), directed by Paul Greengrass, stands out as an exceptional work of art, besides being a moving evocation of the unspeakable tragedy for all the parties involved in the events of January 30, 1972 in London/Derry. Hunger (2008), directed by Steve McQueen, revisits another dramatic episode of the Troubles and the suicidal deaths of 10 republican prisoners in 1981. More recently (i.e. in 2014) Yann Demange made '71, a challenging picture of the early stages of the conflict shown from the point of view of a British soldier. In 2017 Maze was realeased, which once again takes the viewer back to the 1980s and is based on actual events: an escape from the Maze prison. Unlike Five Minutes of Heaven, however, few of the above mentioned films demonstrate a sustained, direct interest in the post-Agreement realities.

\section{All the Beggars Riding}

Likewise, few contemporary novels will look for the victims of the Troubles in $21^{\text {st }}$ century London. On the face of it, All the Beggars Riding by Lucy Caldwell does not look like a post-conflict work of fiction; and yet it is certainly a novel preoccupied with memory and its aporias. Lara, its narrator, is a daughter of a Belfast surgeon who gets killed in a helicopter crash in 1985, at the height of the Troubles. She has lived her entire life - she is nearing forty - in London (with the exception of several brief trips to Belfast), and she knows next to nothing about her father's Irish existence because he has two independent families: a legal one in Northern Ireland and a British lover (Lara's mother) with two children in the UK's capital. Postcolonial and postfeminist issues aside (and those are of paramount importance in the novel and deserve an independent discussion), once Patrick, Lara's father, is killed as a result of the Troubles-related accident in Belfast, his London family also become victims of the Northern Ireland conflict. They are bereft and left homeless; the realisation that they are the 'second-best' family dawns on them when Patrick's wife, Catriona, refuses to communicate with them other than by proxy and they have to agree to her humiliating terms to keep half of the profits from the sale of Patrick's London apartment. In retrospect, when Lara finally decides to revisit the past and make sense of her mother's affair, she wants to produce a memoir in which the theme of reconciliation emerges as particularly significant ${ }^{26}$ Gradually, Caldwell's novel reveals several layers of reconciliation which the reader is invited to explore: between families, between countries, between the past and the present, between the past self and the present self of the narrator, between various characters and finally, perhaps crucially in the context of my argument as well, between fiction and truth recovery.

Lara embarks on her reconstruction of the past-a work of recovery also in the sense that she wants to "save [her] life" ${ }^{27}$ as she puts it—with the firm resolve to be

26 L. Caldwell, All the Beggars Riding, London: Faber \& Faber, 2014, p. 108.

27 Ibidem, p. 40. 
faithful to the facts, "telling the truth, somehow getting to the truth, or towards it". ${ }^{28}$ Soon, however, she has to acknowledge the intrusion of imagination whose help she has enlisted inadvertently:

A handful of pages in, and already it seems that it's going to be impossible to get inside the past, to really be true to it. We can only see it from the outside, squinting back at it, and it changes utterly depending on the mood and circumstances and point from which we happen to be regarding it. There is no one meaning, no correct or tidy interpretation, only a maybe-this, a what-if-that. I didn't know this before. I look back at what I have written so far and it is a halting, juddering hotchpotch of perhaps, but, perhaps. ${ }^{29}$

Interestingly, Lara seeks professional expertise to produce her account of the past. On the pretext of accompanying one of her patients and friends, Mr Rawalpindi, she enrolls in the Introductory Classes to Creative Writing at the Irish Cultural Centre. There, she falls under the spell of a young Irish teacher, who is enthusiastic about fiction's power to change the world. More importantly, the teacher makes Lara realise that whatever she writes - and however much she desires to recapture the truth of the past in it ("fiction is no use to me: I need facts, I need the truth" ${ }^{30}$ ) - it will always be "a kind of story" 31 because of its shape and structure, the emplotment performed by the writer, the view offered in retrospect by someone who both knows the effects of the past on the present and is ignorant of its commonplace minutiae. It is from the Irish teacher that Lara receives the simplest and most succinct definition of fiction, which she can use for her 'reconciliation project': "You say that you're stumbling into blanks, gaps and holes-well, what fiction can do is spin a net across them. It won't catch everything - it can't — but what it can do is make you feel what it might have been like, what it would have been like, to live in that situation, to make that decision. Fiction is the most humane and magical of acts-it's healing, restorative, exactly because it shows us a way across those chasms". ${ }^{32}$ The teacher's advice and encouragement pave the way for Lara's eventual understanding, which is necessary so that she may forgive her mother and let go of her father. ${ }^{33}$

Her writing brings Lara also closer to Belfast, which symbolically represents her departed father. During the Troubles, in her memories, Belfast is a grim, wet, bitter city marked by death and rejection. In fact, her first visit to her father's home town must be recreated on the basis of the CAIN archive because Lara does not remember much (she was four at the time). It is pure guesswork - the weather, what they did, the exact itinerary - though there are flashes of recollection which kindle her imagination. The second visit is on the occasion of her father's funeral and Lara remembers

28 Ibidem, p. 20.

29 Ibidem, p. 28.

30 Ibidem, p. 78.

31 Ibidem, p. 124.

32 Ibidem, p. 124.

33 See ibidem, p. 238. 
the raw and clammy air in "that squalid, hateful city" 34 where the Catholic ritual is held. Her family is not welcome to participate. It is 1985 and the death of Patrick Michael Connolly should be viewed in its proper perspective: the conflict is still going on in Northern Ireland and no one is willing to pay attention to any 'collateral damage'. It will not be until 2006 when The Victims and Survivors Order defines a victim as "someone who has been bereaved as a result of or in consequence of a conflict-related incident". ${ }^{35}$ Towards the conclusion of her narrative, however, Lara goes to Belfast again to meet her half-brother, Michael, and in 2011 her perception of the city is markedly different for two obvious reasons: Belfast itself has undergone a radical makeover and the woman has successfully shed most of the trauma and bitterness, which used to colour her recollections. The newly discovered Belfast, like the memory of her father, who they jointly make peace with, is "a city cupped, cradled in the palm of a hand; a broken creature, something precious". ${ }^{36}$ So many years after her own painful childhood, and after the formal conclusion of the Troubles, alongside its splendour and beauty, Lara can see Belfast's vulnerability. After all, she is half-Irish.

Lara's reconciliation with her Irishness, and with her father's heritage, is not possible until many years after the Troubles, when her mother is gone, too. Caldwell's novel, once summarized, offers the reader a story of sacrifice and total devotion, which one finds quite difficult to credit. Still, its power does lie in its realism. The frame narrative ('The Chernobyl Effect') is crucial here: it makes us realise that, for a rhetorical effect, history and documentary evidence will be invented aplenty, because what matters in this work is truth to the emotion, rather than truth to facts. Lara's memoir evolves into a more general discourse of the disenfranchised, the neglected, the marginalised, the othered and the silenced. Her story is the paradigmatic discourse of vicitimized memory. The only way she can salvage the present from the past is by reimagining the past along fictional lines: that is why All the Beggars Riding subtly alludes, at some points, to other literary texts (e.g. to One by One in the Darkness by Deirdre Madden and to Ghost Light by Joseph O'Connor). All in all, the playful use of metafiction and intertextuality may be Caldwell's way of suggesting that her novel should be read as an elaborate illustration of the power of love, a theme which links All the Beggars Riding with another major contemporary Northern Irish work of fiction, Eureka Street by Robert McLiam Wilson, whose opening sentence reads: "All stories are love stories" ${ }^{37}$ Both novels constitute powerful tributes to enduring affections which prevail despite the tensions and the distressing circumstances of the Troubles.

34 Ibidem, p. 104.

35 Quoted in: A. Duffy, “A Truth Commission for Northern Ireland?”, The International Journal of Transitional Justice 2010, vol. 4, p. 36.

36 L. Caldwell, All the Beggars..., p. 209.

37 R.M. Wilson, Eureka Street, London: Vintage, 1998, p. 1. 


\section{The Truth Commissioner}

The Truth Commissioner by David Park is undoubtedly an emblematic text as far as the crucial categories discussed in this article are concerned. If it explores the past, it is with a view to the future; its message implies that social justice should take precedence over individual justice. But the principal focus of the novel is on the mechanisms of transitional justice, a system of justice which operates in situations when a particular state is in transition from conflict to peace. Also, as a field recently developed in response to specific political and humanitarian needs, transitional justice offers practical solutions and mechanisms intended to remedy unique legal, social and ethical problems. Cheryl Lawther notes that transitional justice often faces difficult and apparently irreconcilable tasks: "the field and its central institutions grapple with the clamour for truth, justice and reconciliation after mass atrocity on one hand, and the desire to bury and silence the past on the other". ${ }^{38}$ It is this tension, which emerges from Lawther's definition, that inspires and informs my reading of Park's novel, as well as my position on remembrance culture in Northern Ireland after 1998. There is a kind of schizophrenia which is inscribed in most truth recovery mechanisms: truth and reconciliation rarely go hand in hand, as for the sake of a consociational future it is often better, it seems, to let sleeping dogs lie.

Truth commissions belong to the key mechanisms of transitional justice. With a clearly defined remit and usually an international body of legal experts, truth commissions are supposed to address past human rights violations, the degree of responsibilities, and consider remedies for the future. On principle, their mission is defined by this double bind: they must recover the past and lay bare what may hurt the peace process and at the same time make an effort to reconcile the recent antagonists and stimulate the healing on a social scale. ${ }^{39}$ As Kirk Simpson notes, in theory truth commissions are about truth recovery but in practice truth yields to politics, and more specifically, to what he calls "the politics of reconciliation":

Whilst there is an undoubted and extremely desirable relationship between truth recovery and reconciliation, too often it has been the case that reconciliation (or some notion thereof) has been advanced at the expense of the recovery of genuine truth, in all its complexity. In addressing the obvious need to provide 'answers' about the past, policymakers can cynically exploit the notion that such inspection must necessarily result in the creation of a sanitised final 'product' - an imposed construction of the past that not only elides the crucial value of atomised individualised stories and experiences, but which actively encourages banal, depersonalised and disconnected readings of history. ${ }^{40}$

38 C. Lawther, "Transitional justice and truth commissions", [in:] C. Lawther, L. Moffett, D. Jacobs (eds.), Research Handbook on Transitional Justice, Cheltenham \& Northampton: Edward Elgar Publishing, 2017, p. 342.

39 P.B. Hayner, Unspeakable Truths..., p. 20.

40 K. Simpson, Truth Recovery in Northern Ireland: Critically Interpreting the Past, Manchester: Manchester University Press, 2009, p. 36. 
Without quoting Park's novel, Simpson makes a point about distortions of the past, a "commodification of memory" ${ }^{41}$ and even about the destruction of social memory. In fact, it would be easy to illustrate all those by examples from The Truth Commissioner. This is what all the major players do in the novel: they try to manipulate justice by bribing or blackmailing witnesses and the Commissioner himself, and someone eventually destroys all the evidence.

Park is skeptical of the effectiveness of a truth commission in Northern Ireland because he does not seem to believe that, despite lofty declarations to the contrary, former terrorists can suddenly become law-abiding citizens committed to the Commission's goals and specifically to the mission of truth recovery. And that concerns both parties to the conflict: the methods that Francis Gilroy's buddies (many of them former IRA members, now Sinn Féin) use are not worse than those employed by MI5. There is more irony, though, in the description of Gilroy as a new minister for culture and education, an obvious allusion to Martin McGuinness. At a certain point Gilroy himself notes the irony when his daughter is about to get married and in his bedroom he finds a new suit delivered for the ceremony: "Armani? Armani his arse. He would like to meet whoever it was cooked that one up. Nice soundbite-former terrorists in Armani suits - but if their paths ever cross he will be able to tell him that the only suits he has ever owned all came from home-shopping catalogues". ${ }^{42}$ Ironically, in the novel Gilroy proves to be an 'innocent' terrorist who will pay the price for someone else's crime because of the Commission's relentless pursuit of truth. After all, in this particular case at least, he is not the one who pulled the trigger even though Michael Madden, a chief witness, is convinced that he saw otherwise. Apparently, people who put too much confidence in their own memory may be dangerous as well.

What Park shows in his novel is a complex web of machinations and mystifications for the sake of the families of the victims and for the sake of the public in the first place. The hearings are carefully staged shows in which nothing is supposed to be left to chance. Witnesses are professionally prepped and taught how to feign remorse and commiseration. Sinn Féin employ spin doctors and lawyers who spend long hours strategizing before crucial hearings. Michael Madden, blackmailed to take the fall for Gilroy (or for whoever really committed the crime), is quite emphatically requested to memorize the following (bogus) disclosure:

If there was any way to change what happened he would grasp it with both hands, whatever it cost him, but he can't bring himself to accept that what now seems like something that happened in a dream, or in a remote and distant land, should have the ability to destroy what he's built for himself. He thinks of parallel universes, of miscarriages of justice and cases of mistaken identity, because whoever he was back then bears no connection to who he is now. Nothing remains, not even the name, so let them do this thing to who he was then, but let who he is now walk away. ${ }^{43}$

$41 \quad$ Ibidem, p. 39.

42 D. Park, The Truth Commissioner, p. 81.

43 Ibidem, p. 315. 
That is the speech that the Commission and the family of the victim want to hear, and Michael is initially persuaded to deliver it. It does not really matter that he did not kill Connor Walshe, a fifteen-year-old Catholic boy who was a police informant executed by the IRA. Sinn Féin want him to make a spurious confession to the Truth Commission; otherwise his new life in the United States will be destroyed and his pregnant girlfriend will be in danger, too. In Park's Belfast, former terrorists may be wearing Armani suits but their methods have not changed that much.

Neither are unionists willing to disclose their secrets to the Commission in Park's novel. James Fenton, a retired police officer in the RUC (which was disbanded and transformed into the Police Service of Northern Ireland), is subpoenaed to testify in the case of Connor Walshe (Fenton was his handler) but his former colleagues impress upon him that there are limits to his disclosures. The public is not supposed to know (at least officially) that the police used to blackmail petty criminals: in exchange for immunity they were expected to snitch on their own people. The police handlers, in turn, usually realised how much the informers risked once caught by the IRA. That is why Fenton does not want to tell the whole truth, and nothing but the truth. In consequence, Park's novel, to quote Matt McGuire, "complicates the very concept of truth recovery upon which mainstream thinking about the post-Troubles era has been based. The Truth Commissioner actively disrupts the republican/loyalist standoff over the question, exposing the false consciousness on both sides, whereby a Northern Irish truth commission is regarded as either a panacea for all ill or yet another concession to a group of unrepentant murderers". ${ }^{44}$ Once the false consciousness on both sides is exposed, they, too, will have to come to terms with the fact that reconciliation and public truth recovery may not necessarily be compatible with each other.

\section{Restorative memory}

Truth itself proves to be a complicated matter both in Park's novel and in the complex post-conflict realities in Northern Ireland. In her book concerned with justice and truth recovery, Marie Breen Smyth discusses a variety of truths which are relevant to the transitional context of peace building: there is obviously the overarching philosophical category of truth but she claims that it is too abstract to be politically useful. ${ }^{45}$ Likewise, religiously inflected concepts of truth disqualify each other as universally (i.e., across denominations and systems of beliefs) useful categories. Within the scope of law and social arrangements (and that is what transitional justice relies on) there is forensic truth which comes down to verifiable facts; to the past that can

${ }_{44}$ M. McGuire, "The Trouble(s) with transitional justice: David Park's The Truth Commissioner", Irish University Review 2017, vol. 47, no. 2, p. 517.

45 M. Breen Smyth, Truth Recovery and Justice After Conflict: Managing Violent Pasts, London $\&$ New York: Routledge, 2007, pp. 22-23. 
be ascertained. Further, transitional justice recognizes narrative truth as well: personal stories told by victims of violence during the process of truth recovery. Then there is dialogical truth which has a social nature and it emerges from interactions between members of a community or members of different communities (possibly opposing communities). Eventually, Breen Smyth mentions restorative truth which is meant to heal the wounds and prevent history from happening again. ${ }^{46}$

What I want to offer-by analogy to Breen Smyth's notion of restorative truth - is a notion of restorative memory in a socio-cultural context. ${ }^{47}$ David Park's novel is an exemplary text which belongs to this cultural category, showcasing "a discourse on reconciliation that often relies on a therapeutic model in which the healing of the wounds left by the past is paramount". ${ }^{48}$ That is why restorative memory, like restorative justice, and unlike retributive justice, does not seek to recover the past at any cost. This may seem paradoxical at heart if we assume that memory's role is to retrieve what is gone by rather than contribute to healing and reconciliation in the first place. However, restorative memory is not necessarily past-oriented just like no individual memory is because, after all, from a psychological perspective, memory remains a function of our present needs and purposes. Cultural memory in a restorative mode is not so much concerned with truth recovery but instead envisages either individual or communal redemption or restitution if those may lead to resolution and reconciliation. Clearly, post-Agreement developments in Northern Ireland prove that entrusting cultural memory with societal healing simulatenously relaxes its commitment to recovering the past. The Truth Commissioner illustrates the workings of restorative memory on a social and political level by making a forceful point about the priority of reconciliation in the present over the dubious notion of public truth recovery (whose truth? how reliable?) and the axiological value of truth itself. It seems that Park recommends societal healing as an act of collective memory, which requires more hope and imagination than recourse to evidence and past facts.

Finally, it is not by accident that restorative memory should come into view in the context of a novel. The Truth Commissioner is concerned with hypothetical realities and imagined pasts, although its historical background is easy to verify. The transition from the "Troubled" past to the post-conflict present, to complete the exorcism of healing and reconciliation, requires the environment of fiction: both Five Minutes of Heaven and All the Beggars Riding make this point crystal clear within their metafictional (or metadramatic) dimension, too. Fiction offers restorative memory a favourable milieu; it promises healing in the sense that it is not preoccupied with past facts but seems to deliver instruction in improving the present. In Caldwell's

46 Ibidem, pp. 24-28.

47 The concept of restorative memory is already in common usage in neuropsychology (see C.A. Mateer, M.M. Sohlberg, Cognitive Rehabilitation: An Integrative Neuropsychological Approach, New York \& London: Guilford Press, 2001, pp. 177-181).

48 A. Rigney, "Reconciliation and remembering: (how) does it work?", Memory Studies 2012, vol. 5, no. 3 , p. 252. 
novel, the narrator confesses that the process of recovering the past has affected her entire life: "Writing my story, I think, in many ways saved my life. It certainly changed everything: the course of bitterness and recrimination and despair that I fear I was set upon. It let me forgive my mother, and let go of my father". ${ }^{49}$ Those words may come from a fictional character but they constitute a formula - what Astrid Erll calls "a literary template" which has the power to shape personal memories and oral life stories ${ }^{50}$ - to be emulated by many readers/viewers who need a convincing script for forgiveness and reconciliation. If those readers/viewers fail to find it in real life, they are likely to embrace imaginary reconciliations, including restorative memories that are conducive to societal healing.

\section{References}

Black, S., "Truth Commission Thrillers”, Social Text 2011, vol. 29, no. 2, pp. 47-66.

Breen Smyth, M., Truth Recovery and Justice After Conflict: Managing Violent Pasts, London \& New York: Routledge, 2007.

Caldwell, L., All the Beggars Riding, London: Faber \& Faber, 2014.

Cohen, D.B., "“Family constellations": An innovative systemic phenomenological group process from Germany", The Family Journal: Counseling and Therapy for Couples and Families 2006, vol. 14, no. 3, pp. 226-233.

Donnelly, K.J., "The Policing of Cinema: Troubled film exhibition in Northern Ireland”, $\mathrm{Hi}$ storical Journal of Film, Radio and Television 2000, vol. 20, no. 3, pp. 385-396.

Duffy, A., “A Truth Commission for Northern Ireland?", The International Journal of Transitional Justice 2010, vol. 4, pp. 26-46.

Erll, A., Memory in Culture, transl. S.B. Young, London: Palgrave Macmillan, 2011.

Fitz-Gibbon, A., Talking to Terrorists, Non-Violence, and Counter-Terrorism: Lessons from Gaza and Northern Ireland, London: Palgrave Macmillan, 2016.

Fraser, T.G., "Historical legacies and the Northern Ireland peace process: Issues of commemoration and memorialisation", Shared Space 2012, vol. 12, pp. 41-50.

Frawley, O., "Introduction: Cruxes in Irish Cultural Memory: The Famine and the Troubles", [in:] O. Frawley (ed.), Memory Ireland, vol. 3: The Famine and the Troubles, Syracuse, NY: Syracuse University Press, 2014, pp. 1-14.

Hackett, C., Rolston B., "The burden of memory: Victims, storytelling and resistance in Northern Ireland", Memory Studies 2009, vol. 3, no. 2, pp. 355-376.

Hayner, P.B., Unspeakable Truths: Transitional Justice and the Challenge of Truth Commissions, New York \& London: Routledge, 2011.

Heidemann, B., Post-Agreement Northern Irish Literature: Lost in a Liminal Space?, London: Palgrave Macmillan, 2016.

Hirschbiegel, O., Five Minutes of Heaven, BBC Films, Big Fish Films, Bórd Scannán na hÉireann, Element Pictures in association with Irish Film Board, Northern Ireland Screen, Pathé! and Ruby Films 2009.

$49 \quad$ L. Caldwell, op. cit., p. 238.

50 A. Erll, Memory in Culture, transl. S.B. Young, London: Palgrave Macmillan, 2011, p. 55. 
Lawther, C., "Transitional justice and truth commissions", [in:] C. Lawther, L. Moffett, D. Jacobs (eds.), Research Handbook on Transitional Justice, Cheltenham \& Northampton: Edward Elgar Publishing, 2017.

Lundy, P., McGovern, M., "Attitudes towards a Truth Commission for Northern Ireland in relation to party political affiliation”, Irish Political Studies 2007, vol. 22, no. 3, pp. 321338.

Mateer, C.A., Sohlberg, M.M., Cognitive Rehabilitation: An Integrative Neuropsychological Approach, New York \& London: Guilford Press, 2001.

McDonald, H., "Northern Ireland violence triggered by ideology and a mistrust of the police", The Guardian, available at: https://www.theguardian.com/uk/2011/jul/12/northern-ireland-violence-ideology-police [access: 13.06.2018].

McGovern, M., “'See No Evil': Collusion in Northern Ireland”, Race \& Class 2017, vol. 58, no. 3, pp. 46-63.

McGuire, M., "Novel truths and post-troubles fiction: Eoin McNamee's The Ultras", Australian Journal of Irish Studies 2015, vol. 15, pp. 55-66.

McGuire, M., "The Trouble(s) with transitional justice: David Park's The Truth Commissioner", Irish University Review 2017, vol. 47, no. 2, pp. 515-530.

Park, D., The Truth Commissioner, London, New Delhi, New York \& Sydney: Bloomsbury, 2009.

Rafferty, T., "After the troubles, telling different stories", The New York Times, available at: https://www.nytimes.com/2009/08/16/movies/16raff.html [access: 13.06.2018].

Report of the Consultative Group on the Past, available at: http://cain.ulst.ac.uk/victims/docs/ consultative_group/cgp_230109_report.pdf [access: 13.06.2018].

Rigney, A., "Reconciliation and remembering: (how) does it work?", Memory Studies 2012, vol. 5 , no. 3, pp. 251-258.

Simpson, K., Truth Recovery in Northern Ireland: Critically Interpreting the Past, Manchester: Manchester University Press, 2009.

The Northern Ireland Peace Agreement, available at: https://peacemaker.un.org/sites/peacemaker.un.org/files/IE\%20GB_980410_Northern\%20Ireland\%20Agreement.pdf [access: 13.06.2018].

Truth - A Sinn Féin Discussion Document, available at: http://www.sinnfein.ie/contents/993 [access: 13.06.2018].

Walsh, D., Independent Commissions and Contentious Issues in Post-Good Friday Agreement Northern Ireland, Cham: Palgrave Macmillan, 2017.

Wilson, R.M., Eureka Street, London: Vintage, 1998. 